University of Nebraska - Lincoln

DigitalCommons@University of Nebraska - Lincoln

Biochemistry -- Faculty Publications

Biochemistry, Department of

July 2004

\title{
Hyaluronan Facilitates Invasion of Colon Carcinoma Cells in Vitro via Interaction with CD44
}

Hyeong-Rok Kim

University of Nebraska - Lincoln

Marie A. Wheeler

University of Nebraska - Lincoln

Christopher M. Wilson

University of Nebraska - Lincoln

Joji lida

University of Nebraska - Lincoln

David Eng

University of Nebraska - Lincoln

See next page for additional authors

Follow this and additional works at: https://digitalcommons.unl.edu/biochemfacpub

Part of the Biochemistry, Biophysics, and Structural Biology Commons

Kim, Hyeong-Rok ; Wheeler, Marie A.; Wilson, Christopher M.; lida, Joji ; Eng, David; Simpson, Melanie A.; McCarthy, James B.; and Bullard, Kelli M., "Hyaluronan Facilitates Invasion of Colon Carcinoma Cells in Vitro via Interaction with CD44" (2004). Biochemistry -- Faculty Publications. 4.

https://digitalcommons.unl.edu/biochemfacpub/4

This Article is brought to you for free and open access by the Biochemistry, Department of at DigitalCommons@University of Nebraska - Lincoln. It has been accepted for inclusion in Biochemistry -- Faculty Publications by an authorized administrator of DigitalCommons@University of Nebraska - Lincoln. 


\section{Authors}

Hyeong-Rok Kim, Marie A. Wheeler, Christopher M. Wilson, Joji lida, David Eng, Melanie A. Simpson, James B. McCarthy, and Kelli M. Bullard 
Published in Cancer Research 64, 4569-4576, July 1, 2004

(c) 2004 American Association for Cancer Research

\section{Hyaluronan Facilitates Invasion of Colon Carcinoma Cells in Vitro via Interaction with CD44}

Hyeong-Rok Kim', Marie A. Wheeler', Christopher M. Wilson², Joji lida², David Eng ${ }^{1}$, Melanie A. Simpson ${ }^{3}$, James B. McCarthy² and Kelli M. Bullard1,2

Departments of 1 Surgery and 2 Laboratory Medicine and Pathology, University of Minnesota, Minneapolis, Minnesota, and ${ }^{3}$ Department of Biochemistry, University of Nebraska, Lincoln, Nebraska

\section{[Abstract] [Full Text] [PDF]}

\section{http://cancerres.aacrjournals.org/cgi/reprint/64/13/4569}

Abstract: Hyaluronan (HA) and its biosynthetic enzymes, HA synthases (HAS1, 2, and 3) are thought to participate in cancer progression. We have shown previously that HA production and HAS3 expression are increased in metastatic colon carcinoma cells (SW620) when compared with cells isolated from a primary tumor (SW480). Because invasion of the extracellular matrix is a fundamental event in tumor growth and metastasis, we hypothesized that SW620 cells would show greater invasive capability than SW480 cells, that invasion is HA dependent, and that HA mediates invasion via interaction with a cell-surface receptor. Invasion into artificial basement membrane (Matrigel) was assessed in vitro. To assess HA functionality, HAS expression was inhibited in SW620 cells by transfection with antisense HAS constructs. Decreased HA secretion and retention in the transfectants were confirmed using competitive binding and particle exclusion assays. SW620 cells demonstrated greater invasion through Matrigel than did SW480 cells. Antisense transfection decreased Matrigel invasion by SW620 cells by $>60 \%$; addition of exogenous HA restored invasion. Because the cell-surface HA receptor CD44 has been implicated in cancer progression, HA-CD44 interaction was then inhibited by incubation with an anti-CD44 antibody. Anti-CD44 antibody impaired invasion into Matrigel by $95 \%$. Taken together, these data suggest that pericellular HA is critical for colon carcinoma cell invasion and that this invasive capability is dependent on interaction with CD44.

The American Association for Cancer Research does not permit posting of this article; an open access version can be downloaded from PubMed Central at the above link. 